\title{
Observations on plant development (VI) Influence of shading on the development of some annual hibernating plants
}

The experiments were carried out on Centaurea cyanus, Viola tricolor, Capsella bursa pastoris (sown May 7), Melandrium album (May 26) and Cerastium viscosum (July 20). With the exception of Cerastium development occurred in most favourable light conditions. The plants sown in pots grew in the garden under natural long summer daylight. The reduction of light intensity (by $50 \%$ ) was achieved by placing over the whole set of plants a gauze-covered frame. Daylength was shortened by covering the plants of the given group with paper hoods provided with perforations for ventilation.

The following combinations were tested:

1. Long day (control series).

2. Long day (shaded with gauze all day).

3. Long day (shaded with gauze from 3 P. M. to dusk).

4. Short day (up to 15 P.M., then deprived of light until 6 A. M.).

5. Short day (shaded with gauze from dawn to 15 P. M., then deprived of light until 6 A. M.).

Temperature maximum and minimum measurement in the particular series carried out at the level of the plants showed in the case of the shaded plants differences as compared with the controls:

for combination 2 average: $\min$. from +0.8 to 2.3 , $\max$. -0.9 to -4.0

for combination 4,5 average: $\min$. from +1.8 to 3.5 , $\max$. -0.9 to -4.0 .

\section{Centaurea cyanus}

The generative development of the plants in the particular long day combinations is shown in Table 1 and in short day combinations in Tab.2.

Budding and flowering is not profuse and the buds develop very slowly. 
Taple 1

\begin{tabular}{|c|c|c|c|c|c|c|c|c|c|c|}
\hline \multirow{4}{*}{ Comb. } & \multicolumn{10}{|c|}{ Count of day from sowing } \\
\hline & \multirow{3}{*}{$\begin{array}{c}37 \\
\text { June } 13 \\
\\
\% \text { of } \\
\text { budding } \\
\text { plants }\end{array}$} & \multicolumn{2}{|c|}{$\begin{array}{c}54 \\
\text { June } 30\end{array}$} & \multicolumn{2}{|c|}{$\begin{array}{c}62 \\
\text { July } 8\end{array}$} & \multicolumn{3}{|c|}{$\begin{array}{c}72 \\
\text { July } 18\end{array}$} & \multicolumn{2}{|c|}{$\begin{array}{c}96 \\
\text { August } 11\end{array}$} \\
\hline & & \multirow{2}{*}{$\begin{array}{c}\% \text { of } \\
\text { budding } \\
\text { plants }\end{array}$} & \multirow{2}{*}{$\begin{array}{c}\% \text { of } \\
\text { flower- } \\
\text { ing } \\
\text { plants }\end{array}$} & \multirow{2}{*}{$\begin{array}{l}\% \text { of } \\
\text { flower- } \\
\text { ing } \\
\text { plants }\end{array}$} & \multirow{2}{*}{$\begin{array}{c}\text { number } \\
\text { of } \\
\text { flowers }\end{array}$} & \multirow{2}{*}{$\begin{array}{c}\% \text { of } \\
\text { flower- } \\
\text { ing } \\
\text { plants }\end{array}$} & \multicolumn{2}{|c|}{$\begin{array}{c}\text { number of } \\
\text { flowers }\end{array}$} & \multirow{2}{*}{$\begin{array}{c}\text { total } \\
\text { number } \\
\text { of } \\
\text { flowers }\end{array}$} & \multirow{2}{*}{$\begin{array}{c}\text { number } \\
\text { of flowers } \\
\text { on one } \\
\text { plant*) }\end{array}$} \\
\hline & & & & & & & total & $\begin{array}{c}\text { on one } \\
\text { plant }\end{array}$ & & \\
\hline 1 & 20 & 100 & 10 & 64 & 26 & 100 & 144 & 2,8 & 1966 & 39.3 \\
\hline 2 & 27 & 100 & 2 & 68 & 34 & 100 & 155 & 3,0 & 1910 & 38.2 \\
\hline 3 & 100 & 100 & 23 & 90 & 52 & 100 & 235 & 4,7 & 2326 & 46.5 \\
\hline
\end{tabular}

- Number of flowers in the course of the whole flowering period.

Table 2

\begin{tabular}{|c|c|c|c|c|c|}
\hline \multirow{2}{*}{ Comb. } & \multirow{2}{*}{$\begin{array}{c}\text { Development } \\
\text { stage in \% of } \\
\text { total number of } \\
\text { plants }\end{array}$} & \multicolumn{4}{|c|}{ Count of days from sowing } \\
\hline & & 72 & 96 & 116 & 123 \\
\hline \multirow[t]{3}{*}{4} & rosette & 69 & 50 & 30 & 23 \\
\hline & stem & 20 & 33 & 52 & 57 \\
\hline & bud & 11 & 17 & 18 & 20 \\
\hline \multirow[t]{3}{*}{5} & rosette & 80 & 64 & 20 & 16 \\
\hline & stem & 15 & 20 & 64 & 60 \\
\hline & bud & 5 & 16 & 16 & 24 \\
\hline
\end{tabular}

\section{Vegetative development}

Under long day. The control series (1) shows retarded growth of the stem (Fig. 1) and the leaf blades as well as slowing down of the rate of leaf differentiation (Table 3). Under short day. Inhibited development of lateral shoots (after 72 days in long day series stem average $20-21 \mathrm{~cm}$, short day, series stem average $4.0 \mathrm{~cm}$ ). Differentiation of leaves at first slow, then rapid, with a long period of leaf formation (Table 3 ).

Table 3

\begin{tabular}{c|c|c|c|r|r}
\hline \multirow{2}{*}{$\begin{array}{c}\text { Count } \\
\text { of days from }\end{array}$} & \multicolumn{5}{|c}{ Total number of leaves per plant } \\
\cline { 2 - 6 } & 1 & 2 & 3 & 4 & \multicolumn{1}{|c}{5} \\
\hline 37 & 11 & 13 & 14 & 9 & 8 \\
58 & 24 & 25 & 25 & 24 & 23 \\
72 & 27 & 31 & 32 & 51 & 44
\end{tabular}


Fresh and dry weight calculated per 1 plant after 72 days are given in Table 4.

Table 4

\begin{tabular}{c|c|c|c|c|c}
\hline $\begin{array}{c}\text { Per } \\
\text { one plant }\end{array}$ & 1 & 2 & 3 & 4 & 5 \\
\hline $\begin{array}{c}\text { Fresh weight } \\
\begin{array}{c}\text { Dry weight } \\
\% \text { of dry } \\
\text { matter }\end{array}\end{array}$ & 2.5 & 7.1 & 9.3 & 4.8 & 6.7 \\
& 23.7 & 21.7 & 23.9 & 16.9 & 14.9
\end{tabular}

\section{Viola tricolor}

The course of generative development under long day is given in Table 5 .

In Viola the influence of reduction of light intensity on the time and intensity of flowering is distinct. The positive effect of the conditions of combination 3 is more marked than in the case of Centaurea.

Table 5

\begin{tabular}{|c|c|c|c|c|c|c|c|c|}
\hline \multirow[b]{3}{*}{ Comb. } & \multicolumn{8}{|c|}{ Count of days from sowing } \\
\hline & \multirow{2}{*}{$\begin{array}{c}55 \\
\text { June } 30 \\
\% \text { of } \\
\text { budding } \\
\text { plants }\end{array}$} & \multicolumn{2}{|c|}{$\begin{array}{c}63 \\
\text { July } 8\end{array}$} & \multicolumn{3}{|c|}{$\begin{array}{c}70 \\
\text { July } 15\end{array}$} & \multicolumn{2}{|c|}{$\begin{array}{c}82 \\
\text { July } 27\end{array}$} \\
\hline & & $\begin{array}{c}\% \text { of } \\
\text { budding } \\
\text { plants }\end{array}$ & $\begin{array}{c}\% \text { of } \\
\text { flowering } \\
\text { plants }\end{array}$ & $\begin{array}{c}\% \text { of } \\
\text { flowering } \\
\text { plants }\end{array}$ & $\begin{array}{c}\text { total } \\
\text { number } \\
\text { of flowers }\end{array}$ & $\begin{array}{c}\text { number of } \\
\text { flowers } \\
\text { on one } \\
\text { plant }\end{array}$ & $\begin{array}{c}\text { total } \\
\text { number } \\
\text { of flowers } \\
\text { + buds }\end{array}$ & $\begin{array}{l}\text { number } \\
\text { of flowers } \\
+ \text { buds on } \\
\text { one plant }\end{array}$ \\
\hline 1 & 17.0 & 77 & 30 & 100 & 112 & 2.0 & $979+279$ & $20+4.8$ \\
\hline 2 & 4.7 & 64 & 27 & 79 & 78 & 1.4 & $772+258$ & $16+5.4$ \\
\hline 3 & 41.0 & 92 & 65 & 100 & 138 & 2.4 & $1056+240$ & $22+5.0$ \\
\hline
\end{tabular}

Under short day the first plants flowered only after 97 days (i.e. when the flowering of the plants of the long day series was over or when they were in full bloom). Up to the end of September in both short-day combinations only few plants came into flower developing only a small number of flowers. As regards vegetative development, there was not much difference between the long-day ccmbinations in the number of leaves, of lateral shoots, in the dry and fresh weight.

The leaves were somewhat longer in combination 2 . The main stem was longest in combination 2 and shortest in combination 1. 
In the short-day combinations the main stem and the leaf bIades were longer in combination 5 .

After 72 days the average length of the leaf blade in combination 5 was $3.2 \mathrm{~cm}$, in combination $3-2.4 \mathrm{~cm}$. In comparison to the long day series the growth of the stem was slower, the leaves shorter (particularly in comb. 4). Weight increase was much slower (Table 6).

Table 6

\begin{tabular}{|c|c|c|c|c|c|c|}
\hline & $\begin{array}{l}\text { Weight of one } \\
\text { plant }\end{array}$ & 1 & 2 & 3 & 4 & 5 \\
\hline $\begin{array}{l}\text { Period of full bloom, } \\
\text { plants under long day } \\
\text { (74th day from sow- } \\
\text { ing) }\end{array}$ & $\begin{array}{c}\text { fresh } \\
\text { dry } \\
\% \text { of dry } \\
\text { matter }\end{array}$ & $\begin{array}{r}7.9 \\
1.1 \\
13.9\end{array}$ & $\begin{array}{r}7.4 \\
0.9 \\
12.1\end{array}$ & $\begin{array}{r}11.1 \\
1.5 \\
13.6\end{array}$ & $\begin{array}{l}1.5 \\
0.17 \\
11.3\end{array}$ & $\begin{array}{l}3.4 \\
0.3\end{array}$ \\
\hline $\begin{array}{l}\text { Period of sporadic flo- } \\
\text { wering of plants un- } \\
\text { der short day (138th } \\
\text { day from sowing) }\end{array}$ & $\begin{array}{c}\text { fresh } \\
\text { dry } \\
\% \text { of dry matter }\end{array}$ & $\begin{array}{l}- \\
- \\
-\end{array}$ & - & - & $\begin{array}{r}6.8 \\
\\
1.4 \\
20.7\end{array}$ & $\begin{array}{r}1.4 \\
25.0\end{array}$ \\
\hline
\end{tabular}

\section{Melandrium album}

Similarly as in the case of the two preceding plants flowering is earlier and more intensive in combination 3 (Table 7).

Table 7

\begin{tabular}{|c|c|c|c|c|c|c|c|c|c|}
\hline \multirow{4}{*}{ Comb. } & \multicolumn{9}{|c|}{ Count of days from sowing } \\
\hline & \multirow{3}{*}{$\begin{array}{c}41 \\
\text { July } 6 \\
\% \text { of } \\
\text { budding } \\
\text { plants }\end{array}$} & \multirow{3}{*}{\begin{tabular}{|c|}
46 \\
July 11 \\
\\
$\%$ of \\
budding \\
plants
\end{tabular}} & \multicolumn{2}{|c|}{$\begin{array}{c}53 \\
\text { July } 18\end{array}$} & \multicolumn{2}{|c|}{$\begin{array}{c}61 \\
\text { July } 26\end{array}$} & \multicolumn{3}{|c|}{$\begin{array}{c}77 \\
\text { August } 11\end{array}$} \\
\hline & & & \multirow{2}{*}{$\begin{array}{c}\% \text { of } \\
\text { budding } \\
\text { plants }\end{array}$} & \multirow{2}{*}{$\begin{array}{c}\% \text { of } \\
\text { flower- } \\
\text { ing } \\
\text { plants }\end{array}$} & \multirow{2}{*}{$\begin{array}{l}\% \text { of } \\
\text { flower- } \\
\text { ing } \\
\text { plants }\end{array}$} & \multirow{2}{*}{$\begin{array}{c}\text { number } \\
\text { of } \\
\text { flowers }\end{array}$} & \multirow{2}{*}{$\begin{array}{c}\% \text { of } \\
\text { flowering } \\
\text { plants }\end{array}$} & \multicolumn{2}{|c|}{ Number of buds } \\
\hline & & & & & & & & total & $\begin{array}{c}\text { on one } \\
\text { plant }\end{array}$ \\
\hline 1 & 0 & 65 & 100 & 10 & 90 & 217 & 100 & 445 & 11.1 \\
\hline 2 & 12.5 & 75 & 100 & 25 & 92 & 226 & 100 & 511 & 12.8 \\
\hline 3 & 25.0 & 100 & 100 & 87 & 100 & 330 & 100 & 537 & 13.4 \\
\hline
\end{tabular}

Under short day part of the plants developed stems and formed buds after 111 days: in combination 4 - about $20 \%$ and in combination 5 only sporadically.

After 144 days (in the glasshouse) all the plants of combination 4 and most of combination 5 developed single buds and flowers. 
The number of leaves was more or less the same in all combinations. Lateral shoots were less numerous in combinations 4 and 5 and no differences between the combinations under long day were found.

The growth of the main stem (see Fig. 1) was quickest in combination 3, somewhat slower in combinations 2 and 1 . In the short day

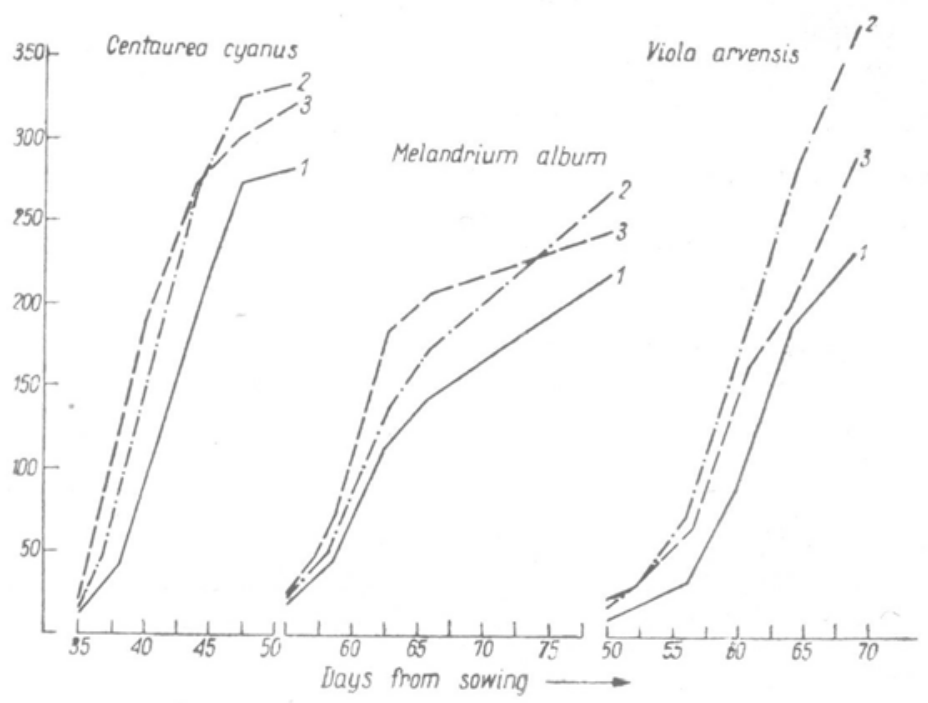

Fig. 1. The growth of the main stem (Average from 25 plants)

1 - Control; 2 - Long Day, Shaded all Day; 3 - Long Day, Shaded From 3 PM

series the main stem does not attain the height of the plants under long day; it is shortest in combination 5 (after 111 days in comb. 5 on the average $3.8 \mathrm{~cm}$, in comb. 4 - av. $7.0 \mathrm{~cm}$.).

The length of the successive leaves shows distinct differences in the particular combinations (Table 8 gives the maximum average length of the individual leaves). The leaves were distinctly longer in combinations 2 and 3.

Table 8

\begin{tabular}{c|r|r|r|r|r}
\hline \multirow{2}{*}{ Comb. } & \multicolumn{5}{|c}{ Successive leaves } \\
\cline { 2 - 6 } & I & II & III & IV & V \\
\hline 1 & 26 & 81 & 100 & 97 & 76 \\
2 & 33 & 89 & 115 & 123 & 110 \\
3 & 32 & 93 & 100 & 115 & 108 \\
4 & 20 & 39 & 65 & 76 & 67 \\
5 & 25 & 45 & 74 & 75 & 73
\end{tabular}


Dry and fresh weight are summarized in Table 9.

Table 9

\begin{tabular}{|c|c|c|c|c|c|c|}
\hline & Per one plant & 1 & 2 & 3 & 4 & 5 \\
\hline $\begin{array}{l}\text { Stage of general budd- } \\
\text { ing and partialflower- } \\
\text { ing of long day plants } \\
\text { (54th day from sow- } \\
\text { ing) }\end{array}$ & $\begin{array}{l}\text { fresh weight } \\
\text { dry weight } \\
\% \text { of dry } \\
\text { matter }\end{array}$ & $\begin{array}{c}12.6 \\
1.02 \\
8.1\end{array}$ & $\begin{array}{c}13.4 \\
1.23 \\
9.1\end{array}$ & $\begin{array}{c}12.6 \\
0.96 \\
7.6\end{array}$ & $\begin{array}{l}3.3 \\
0.15 \\
4.6\end{array}$ & $\begin{array}{l}4.0 \\
0.14 \\
3.5\end{array}$ \\
\hline $\begin{array}{l}\text { Budding stage of short } \\
\text { day plants (144th day } \\
\text { from sowing) }\end{array}$ & $\begin{array}{l}\text { fresh weight } \\
\text { dry weight } \\
\% \text { of dry matter }\end{array}$ & $\begin{array}{l}- \\
-\end{array}$ & $\begin{array}{l}- \\
-\end{array}$ & $\begin{array}{l}- \\
- \\
-\end{array}$ & $\begin{array}{c}14.1 \\
2.24 \\
15.9\end{array}$ & $\begin{array}{c}17.2 \\
2.51 \\
14.1\end{array}$ \\
\hline
\end{tabular}

Capsella bursa pastoris (Tables 10 and 11).

Table 10

\begin{tabular}{l|c|r|r|r|r|r}
\hline & $\begin{array}{c}\text { Count of days } \\
\text { from sowing }\end{array}$ & 1 & 2 & 3 & 4 & 5 \\
\cline { 3 - 7 } & 44 & 36 & 20 & 48 & 6 & 0 \\
\hline \% of budding plants & 49 & 100 & 80 & 88 & 12 & 0 \\
\% of flowering plants & 59 & 100 & 100 & 100 & 74 & 40
\end{tabular}

Table 11

\begin{tabular}{l|r|r|r|r|r}
\hline & \multicolumn{5}{|c}{ 59th day from sowing } \\
\cline { 2 - 6 } \multicolumn{1}{c|}{} & \multicolumn{1}{|c|}{1} & 2 & \multicolumn{1}{c}{3} & 4 & 5 \\
\hline Number of leaves & 12.0 & 15.0 & 13.0 & 14.0 & 12.0 \\
Average length of leaves & 7.9 & 10.0 & 8.7 & 7.0 & 6.2 \\
Height of inflorescence stem & 21.6 & 22.6 & 23.8 & 4.4 & 2.9 \\
Fresh weight (1 plant) & 4.1 & 4.6 & 4.5 & 1.2 & 0.9 \\
Dry weight (1 plant) & 1.5 & 1.4 & 1.3 & 0.3 & 0.2 \\
\% of dry matter & 36.6 & 30.4 & 29.0 & 26.9 & 28.6
\end{tabular}

In the distinct heliophyte, Capsella, shading as well as reduction of daylight together with shading causes a delay in the generative development.

Cerastium viscosum (sown July 20).

Some of the plant development indices based on measurements on the 52-nd day after sowing (Sept. 10) are presented in Table 12. 
Table 12

\begin{tabular}{l|r|r|r|r|r}
\hline & 1 & 2 & 3 & 4 & 5 \\
\hline $\begin{array}{l}\text { \% of budding and flowering } \\
\text { plants }\end{array}$ & 60.0 & 48.0 & 72.0 & spor. & spor. \\
Mean height of main stem & 4.8 & 8.1 & 5.9 & 3.7 & 5.4 \\
Average number of lateral & & & & & \\
$\quad$ shoots & 11.0 & 11.0 & 11.0 & 9.0 & 11.0 \\
Fresh weight (1 plant) & 4.0 & 4.7 & 3.7 & 3.2 & 3.7 \\
Dry weight (1 plant) & 0.5 & 0.6 & 0.5 & 0.3 & 0.4 \\
\% of dry matter & 12.4 & 12.6 & 12.4 & 10.4 & 10.8
\end{tabular}

\section{DISCUSSION OF RESULTS}

\section{Generative development}

Under long day the plants of combination 3 (shaded from 3 P. M.), as compared with the controls and combination 2 enter earlier into the generative stage, and show more intensive flowering.

As far as the influence of continual reduction of light intensity is concerned, Viola, Capsella and Cerastium, as compared to the control series show a somewhat retarded budding and flowering, while Centaurea and Melandrium on the contrary are slightly precocious. These differences, however, are soon equalised.

Under short day part of the plants or only single ones come into flower with a greater delay. This retardation was particularly marked in combination 5 , i.e. under short day with shading.

\section{Vegetative development}

Under long day differences were found to occur between the various combinations. They are summarized in Table 13 (both positive and negative deviations from the controls).

Table 13

\begin{tabular}{|c|c|c|c|c|c|c|c|c|c|c|}
\hline \multirow{2}{*}{ Combination } & \multicolumn{2}{|c|}{ Centaurea } & \multicolumn{2}{|c|}{ Viola } & \multicolumn{2}{|c|}{ Melandrium } & \multicolumn{2}{|c|}{ Cerastium } & \multicolumn{2}{|c|}{ Capsella } \\
\hline & 2 & 3 & 2 & 3 & 2 & 3 & 2 & 3 & 2 & 3 \\
\hline Length of main stem & ++ & + & ++ & + & ++ & ++ & ++ & + & + & + \\
\hline Number of leaves & 0 & 0 & 0 & 0 & 0 & 0 & & & + & 0 \\
\hline Length of leaves & ++ & + & + & 0 & $+(+)$ & + & & & ++ & $(+)$ \\
\hline $\begin{array}{l}\text { Number of lateral } \\
\text { shoots }\end{array}$ & 0 & 0 & 0 & 0 & $(-)$ & 0 & 0 & 0 & $\cdots$ & - \\
\hline I resh weight & - & + & 0 & + & $(+)$ & 0 & $(+)$ & $(-)$ & $(+)$ & $(+)$ \\
\hline Dry weight & - & $(+)$ & 0 & $(+)$ & $(+)$ & 0 & $(0)$ & $(0)$ & 0 & $(\rightarrow)$ \\
\hline$\%$ of dry matter & - & 0 & $(-)$ & $(0)$ & $(+)$ & $(-)$ & 0 & 0 & 一 & - \\
\hline
\end{tabular}


Shading speeds up extension growth of the stem and leaves in combination 2, less in combination 3 .

A certain decrease of weight occurs in some species in combination 2. Both combinations of the short day series show a strong inhibition of stem growth and of the development of lateral shoots, the leaves are distinctly shorter, fresh and dry weight as well as the percentage of dry matter are lower as compared with long-day plants of the same age. The vegetative period is very long, therefore, at the time when the plants under short day come into flower, particularly their dry weight and the percentage of dry matter are higher than those of plants under long day in the flowering period. The differences in the development of plants in combinations 4 and 5 are insignificant. In the latter combination as compared with 4 a certain acceleration of the stem growth is observed and the leaves are somewhat longer (with the exception of Capsella).

The differences in the growth rate of the stem, the intensity of development of lateral shoots and the size of the leaves become evident when we observe plants growing under different light conditions.

Faster extension growth (with simultaneous lesser thickness of the stem and larger surface of the leaf blades) is frequently observed in plants growing in the glasshouse in winter under continuous daylight. This may be due to the lower light intensity and changes in the light spectrum (less intensive ultraviolet, increased contribution of infrared). The frequently observed enlargement of the leaf blades seems to corroborate this concept. The influence of red rays on the growth of the stem and the leaf blades (extension) has frequently been observed (Went 1941, Withrow 1941 quoted after Bunning, lately Powell and Griffith 1960).

The inhibition of stem and leaf blade growth observed in plants sown in late summer and autumn appears to be a reaction to the reduced daylength (Arney is of the same opinion, quoted after Lang 1957). Analogous diminution of the leaf blades is cbserved in plants growing in winter under short day conditions (only Lithospermum and Potentilla reptans were found to have a larger leaf surface under short day).

The accelerated extension growth of the stem and leaf blades observed in combinations 2 and 3 of our experiments cannot be explained by changes in the spectral composition of light. The true cause may rather lie, besides the influence of light intensity, in the somewhat higher night and lower day temperature under the gauze covering and also in the higher air humidity. 
M. S. Kamel (1958) in experiments on the influence of shading on the development of barley observed that, as the light intensity fell, the length of the internodes increased as well as the length and surface of the leaves, while fresh weight and the percentage of dry matter decreased, the growth period and the length of the vegetative stage were prolonged.

It seems possible to determine precisely the influence of light conditions on growth processes, although the effect on the plants of the values of the particular parameters ensuring these conditions varies in the annual cycle.

A certain delay in the generative processes and their reduced intensity in the case of plants reared under reduced light intensity (comb. 2 also 5 as compared with 4) is understandable, even if we assume an only indirect action on the development via the effect on growth and assimilative productivity.

More difficult to explain is the fact of a certain hastening of flowering and of its increased intensity in combination 3 .

This hastening is undoubtedly the result of interaction of various factors influencing development and growth, which, however, under the conditions of our experiments could not be quantitatively determined. Plants shaded from 3 P. M. in comparison to the controls had somewhat better air humidity conditions (in 1960 owing to heavy rainfall air humidity was in general relatively high); the influence of wind was weaker, temperature conditions were somewhat more favourable (particularly in the night) and the contribution of red rays in late afternoon hours was perhaps smaller. In ccmparison to the combination shaded all day, the plants of combination 3 had normal light conditions up to 3 P. M., i.e. in the period of intensive assimilation.

In connection with the results obtained a remark of W e n t (p. 241) is interesting. He states namely that the critical limit of light intensity for tomato growth lies at about $1000 \mathrm{~m}$-candles, while for fructification it is lower. Anyway, notwithstanding the accuracy of this limit, it is attained in the early afternoon hours, if the plant is in the shade at the time. Thus, if night temperature is too low for optimum growth, then an eastward exposure will be more favourable than a westward one. The author adds: „In general when plants are grown in too cool climate eastern exposure should improve growth (if this is largely controlled by nyctotemperature) or in other words afternoon shade is beneficial. This is a paraphrase of the well known gardener's dictum that the morning sun is best for plants". 


\section{REFERENCES}

Bunning E., 1953, Entwicklung- und Bewegungsphysiologie der Pflanzen, p. $430-436$.

$\mathrm{K}$ a mel M. S., 1958, Efficiency of solar energy conversion as related with growth of barley, Meedeling. Landb. Hagesch 58 (8) Wageningen.

K a mel M. S., 1959, A physiological study of shading and density effects on the growth and the efficiency of solar energy conversion in some field crops. Medeling Landb. Hagesch. 59. (3) Ref. Field Crops Abstract 13. No. 21960 (p. 138-139).

L a $\mathrm{n}$ g A., 1955, a, Entwicklungsphysiologie Fortschritte d. Botanik. 17. 1955 (p. 757 \& following 765 . b, ibid. 19. 1957 (pp. 365-66 \& 373-375).

Listowski A., J eśmi a n ow i c z A., 1960, Beitrag zur Erkennung der Zusammenhänge zwischen Entwicklung und Umweltsbedingungen einiger Pflanzen, Roczn. N. Roln. 81-A-2.

Listowski A., J a ckowska I., Observations the influence of exterior conditions on plant development IV. The development of annual hibernating plants. Acta Soc. Bot. Pol. (in press).

Powell R., Griffith M., 1962, Some Anatomical Effects of Kinetin and Red Light on Disks of Bean Leaves, Plant Phys. 35 (2).

W a s sink E. C., S t o l w i jk J., 1956, Effects of Light Quality on Plant Growth, Ann. Rev. of Pl. Phys. 7.

W en t Fr., 1957, The Experimental Control of Plant Growth. 